DOI: https://doi.org/10.25146/2587-7844-2020-12-4-62

\title{
УДК 81'23
}

\section{ОБРАЗ ЖЕНЩИНЫ В ЯЗЫКОВОМ СОЗНАНИИ ЖИТЕЛЕЙ ПРИЕНИСЕЙСКОЙ СИБИРИ}

\section{Т.В. Мамаева (Красноярск, Россия)}

\section{Аннотация}

Постановка проблемы. В статье рассматривается образ женщины в языковом сознании жителей Приенисейской Сибири, выявляются специфические черты регионального языкового сознания. Источником исследования послужили данные Ассоциативного словаря Приенисейской Сибири (от стимула к реакции). Анализ данных словаря позволяет выявить основные черты исследуемого образа в языковом сознании сибиряков, что и является объектом нашего исследования.

Цель данной работы - выявление психолингвистического восприятия образа женщины жителями Приенисейской Сибири.

Meтоды исследования. Для выявления ценностных смыслов образа женщины осуществляем исследование путем анализа представленных в словаре ассоциаций от стимула к реакции, что позволяет показать общие представления о женщине как культурном стереотипе.

Результаты исследования. В результате анализа мы пришли к следующему выводу: образ женщины в региональном сибирском сознании ассоциируется с мамой, красотой, роковым влечением, независимым характером, грацией, любовью. Основная роль женщины, по мнению представителей Красноярского края, - быть матерью, мамой, женой, любимой, бабушкой, бабой, проявляющей в соответствующих ситуациях как женские, так и мужские качества.

Ключевые слова: психолингвистика, языковое сознание, ассочииативный эксперимент, ассоциативное поле, иеенность, ассочиативный словарь, Приенисейская Сибирь.

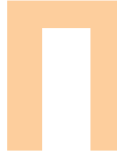

остановка проблемы. Современная женщина сегодня рассматривается не только в качестве домохозяйки, верной жены и хорошей матери. Карьерный рост, устойчивый социальный статус, финансовая независимость давно стали приоритетными. Учитывая тот факт, что ценностный аспект языковой личности связан с уровнем зрелости того или иного человеческого сообщества, социальная норма является частью ценностной картины мира, а значит, ценности выступают определяющим фактором при образовании системы социальных норм.

Обзор научной литературьл. По мнению Е.Ф. Тарасова, «материалом для вскрытия содержания общечеловеческих цннностей в конкретной этнической культуре служат: тексты, овнешняющие этические прескрипции от имени социума (статьи в научных энциклопедиях и трудах аксиологов); экспериментальные данные, в которых в ходе психолингвистических экспериментов овнешняется общественное обыденное сознание профанных носителей культуры (ассоциативные поля, семантические пространства, семантические категории-факторы, различные графики и профили, представляющие результаты психосемантического эксперимента и т.п.)» [Тарасов, 2012, с. 13]. 
«Изучение языкового сознания методом ассоциативного эксперимента привлекает своей возможностью воссоздания образа мира через различные формы его „овнешнения”. Путем анализа ассоциативных полей „от стимула к реакции” можно получить ассоциативный портрет испытуемых, выявить общие и специфические черты образа (картины) мира русских в зависимости от возраста, пола, территории проживания» [Васильева и др., 2017, с. 12]. Н.В. Уфимцева отмечает также, что «Ассоциативное поле, как результат ассоциативного эксперимента, является фрагментом вербальной памяти человека, отраженного в сознании среднего носителя той или иной культуры, его мотивов и оценок и, следовательно, его культурных стереотипов» [Уфимцева, 1996, с. 153].

Образ женщины не раз становился объектом психолингвистического исследования: концепт «женщина» в русском языковом сознании рассматривался Л.В. Адониной [Адонина, 2007]; лексикографическую и психолингвистическую репрезентацию образа женщины в русской, хакасской и английской культурах представили Т.Г. Боргоякова и К.А. Покоякова [Боргоякова, Покоякова, 2012]; ценностный потенциал оппозиции «мужчина / женщина» изучала Е.В. Устьянцева [Устьянцева, 2017] и многие другие.

Цель данной работы - выявление психолингвистического восприятия женщины жителями Приенисейской Сибири.

Методы исследования. Для выявления ценностных смыслов образа женщины осуществляем исследование путем анализа представленных в словаре ассоциаций от стимула к реакции, что позволяет показать общие представления о женщине как культурном стереотипе.

Результаты исследования. Рассмотрим представление о женщине в языковой картине мира енисейских сибиряков. Ассоциативное поле «Женщина» включает 70 реакций. Ядерная зона представлена реакциями с частотой от 11 до 4 и включает следующие лексемы: мать 11, красивая 6, мужчина 4. Как видим, доминирующей здесь является реакция «мать», то есть для большинства респондентов образ женщины связан с самым родным человеком, мамой. Отметим, что на стимул «Мама» было дано всего 2 реакции «Женщина». Оставшиеся реакции красивая и мужчина указывают на женскую красоту и «парность» женщины. Обратившись к стимулу «Мужчина» отмечаем самое большое количество данных реакций - женщзна 17 , что еще раз подчеркивает важность существования в паре в сибирском образе мира.

В формировании представления о ментальности, о жизненных идеалах немаловажную роль представляет зона околоядерная. Здесь встречаем такие реакции: кошка 3, вамn 3, любимая 2. Зона небольшая по количеству данных реакций, но интересная с точки зрения содержания. Реакция кошка может говорить о разных представлениях: женской грации, известном психотипе женщина-кошка, представляющем красивую, свободолюбивую, самостоятельную и притягательную для мужчин даму, некоторых качествах женской натуры и под. Выражение «кош$\kappa a$, которая гуляет сама по себе», вошедшее в оборот из одноименной сказки 
Р. Киплинга, всегда относится к женщине, и такой образ полностью вбирает значение фразеологизма. Реакция вамп показывает распространенный в литературе и кино образ сексапильной женщины, женщины роковой, которая манипулирует мужчинами посредством флирта, влечет мужчин помимо воли. Отчасти реакции кошка и вамп пересекаются, образуют сложный образ самодостаточной женщины, сугубо своевольной, красивой, часто получающей все, что ей нужно, посредством мужчин. Реакция любимая говорит сама за себя - жители Приенисейской Сибири вкладывают любовь к женщине в ее образ.

Периферийная зона слова-стимула «Женщина» включает 41 лексему с частотой 1, среди которых: в белом, бледность, деньги, молодая, коварная, ребенок, полигамность, лгать, Настя, обман, измена, уют, красивое, мечты, незыблемое, бизнес-леди, жена, мужественный, бабушка, любима, любовь, в черном, лучиая, прекрасна, мама, большая, возраст, не очень, баба, знаменитая, Ева, свободная, обаятельная, в иляпе, сильная, пожилая, Родина и др.

Сибирское языковое сознание периферийной зоны включает как положительные, так и отрицательные реакции, указывающие: на возраст -молодая, возраст, пожилая; внешность - бледность, прекрасна, не очень, баба, обаятельная, большая, красивое; физические и моральные качества женщины - коварная, ребенок, лгать, обман, измена, мужественный, свободная, сильная; литературный образ, образ искусства - в белом (роман писателя Уилки Коллинза «Женщина в белом»), в черном (роман английской писательницы Сьюзен Хилл «Женщина в черном», по которому был снят мистический фильм ужасов), в шляпе (картина А. Матисса «Женщина в шляпе»); социальную роль / статус - мама, бабуика, жена, бизнеследи / знаменитая; отношение женщины / к женщине - любовь, любима, Родина, деньги, за товар; реакции-имена - Настя, Ева; свойство / состояние / способность: незыблемое, вечность, мечты, уют; нет реакции - 1 человек.

Формально-грамматическая характеристика состава ассоциативного поля «Женщина» различна. Первое место по частоте занимает имя существительное 28 (60 \%), второе место - имя прилагательное - 15 (34 \%), третье - глагол - 1 (2 \%) и наречие - 1 (2 \%), нет реакции - 1 (2\%). Таким образом, учитывая номинацию, предметность, передаваемые именем существительным, можно говорить о неизменном, «незыблемом» представлении о женщине в языковом сознании жителей Приенисейской Сибири. В образе закреплены как положительные стороны (мать, мама, бабушка, жена, Родина, уют, вечность, ребенок, мечтьл и др.), так и отрицательные (деньги, за товар, лгать, обман, измена, баба, коварная и др.). Самая большая по числу реакций группа в периферийной зоне указывает на физические, моральные качества и внешность женщины.

Обратим внимание, что лексема баба, на наш взгляд, одинаково относится к двум группам: внешность и физические и моральные качества женщины. Реакция Ева указывает как на библейский образ праматери человечества, так и на имя собственное. 
Bblводы. Подводя итог, отмечаем, что в сознании сибиряков образ женщины ассоциируется с мамой, красотой, роковым влечением, независимым характером, грацией, любовью. В языковом сознании жителей Приенисейской Сибири образ женщины также неразрывно связан с образом мужчины.

Основная роль женщины, по мнению представителей Красноярского края, быть матерью, мамой, женой, любимой, бабушкой, бабой, женщиной-кошкой, бизнес-леди, проявляющей в соответствующих ситуациях как женские, так и мужские качества, показывающей многогранность женской натуры, способность перевоплощаться, совмещать в себе многие образы одновременно, одинаково хорошо играть роли, на которые приглашает жизнь. Такой образ соответствует и современной тенденции женщин посвящать себя карьере, добиваться финансовой независимости, но и оставаться в качестве домохозяйки, верной жены и хорошей матери.

Формально-грамматический состав указывает на статичность, незыблемость образа женщины, закрепленного в сибирском региональном сознании.

\section{Список словарей}

1. Васильев А.Д., Васильева С.П., Кипчатова А.В., Шибаев М.В., Тимченко А.Г., Бебриш Н.Н. Ассоциативный словарь Приенисейской Сибири / Краснояр. гос. пед. ун-т им. В.П. Астафьева. Красноярск, 2014. 258 с.

2. Ожегов С.И. Толковый словарь русского языка / под общ. ред. проф. Л.И. Скворцова. 24-е изд., испр. М.: Оникс: Мир и образование, 2010. 640 с.

\section{Библиографический список}

1. Адонина Л.В. Концепт «женщина» в русском языковом сознании: дис. ... канд. филол. наук. Воронеж, 2007. 246 c.

2. Боргоякова Т.Г., Покоякова К.А. Лексикографическая и психолингвистическая репрезентация образа женщины в разных культурах // Вестник НГУ. Сер.: Лингвистика и межкультурная коммуникация. 2012. Т. 10, вып. 2. С. 45-50.

3. Васильева С.П., Васильев А.Д., Т.В. Мамаева Е.В. Устьянцева Базовые ценности регионального языкового сознания русских Приенисейской Сибири: монография / Краснояр. гос. пед. ун-т им. В.П. Астафьева. Красноярск, 2017. 180 с.

4. Тимченко А.Г. Лексическая экспликация семиотической оппозиции «мужчина / женщина» в говорах центральных районов Красноярского края // Слово и текст в культурном сознании эпохи: сб. науч. тр. / Вологод. гос. пед. ун-т. Вологда, 2012. С. 250-256.

5. Тарасов Е.Ф. Проблема анализа содержания общечеловеческих ценностей // Вопросы психолингвистики. 2012. № 1 (15). С. 8-17.

6. Устьянцева Е.В. Оппозиция мужчина - женщина в языковом сознании сибиряков // Базовые ценности этноса в речи и тексте: материалы международной научно-практической конференции / Краснояр. гос. пед. ун-т им. В.П. Астафьева. Красноярск, 2017. С. 261-269.

7. Уфимцева Н.В. Русские: опыт еще одного самопознания // Этнокультурная специфика языкового сознания. М.: Ин-т языкознания РАН, 1996. С. 144-162.

\section{Сведения об авторе}

Мамаева Татьяна Владимировна - кандидат филологических наук, доцент кафедры общего языкознания, Красноярский государственный педагогический университет им. В.П. Астафьева; e-mail: mamaevatv@yandex.ru 
DOI: https://doi.org/10.25146/2587-7844-2020-12-4-62

\section{THE IMAGE OF A WOMAN IN LINGUISTIC CONSCIOUSNESS OF THE YENISEI SIBERIA INHABITANTS}

\section{T.V. Mamaeva (Krasnoyarsk, Russia)}

\section{Abstract}

Statement of the problem. The article examines the image of a woman in linguistic consciousness of the Yenisei Siberia inhabitants, identifies specific features of the regional linguistic consciousness. The study was based on data from the Associative dictionary of the Yenisei Siberia (from stimulus to reaction). Such analysis allows us to identify the main features of the studied image in the linguistic consciousness of Siberians, which is the object of our research.

The purpose of this study is to identify the psycholinguistic perception of a woman by residents of the Yenisei Siberia.

Research methods. To identify the value meanings of the image-concept "woman", we conduct research by analyzing the associations presented in the dictionary from stimulus to reaction, which allows us to show general ideas about a woman as a cultural stereotype.

Research results. As a result of the analysis, we came to the following conclusion: the image of a woman in the regional Siberian consciousness is associated with mother, beauty, fatal attraction, independent character, grace, and love. The main role of a woman, according to the representatives of the Krasnoyarsk territory, is to be a mother, mom, wife, beloved woman, grandmother, woman, who shows both female and male qualities in appropriate situations.

Keywords: psycholinguistics, linguistic consciousness, associative experiment, associative field, associative dictionary, value, Prieniseyskaya Siberia.

\section{Spisok slovarej}

1. Vasil'ev A.D., Vasil'eva S.P., A.V. Kipchatova, SHibaev M.V., A.G. Timchenko, N.N. Bebrish Associativnyj slovar' Prienisejskoj Sibiri. Krasnoyarsk: KGPU im. V.P. Astaf'eva, 2014. 258 s.

2. Ozhegov S.I. Tolkovyj slovar' russkogo yazyka / pod obshch. red. prof. L.I. Skvorcova. 24-e izd., ispr. M.: Oniks: Mir i obrazovanie, 2010. $640 \mathrm{~s}$.

\section{References}

1. Adonina L.V. Koncept "zhenshchina" v russkom yazykovom soznanii [The concept of "woman" in the Russian linguistic consciousness]. Dis. kand. filol. nauk. Voronezh, 2007. 246 p.

2. Borgoyakova T.G., Pokoyakova K.A. Leksikograficheskaya i psiholingvisticheskaya reprezentaciya obraza zhenshchiny v raznyh kul'turah [Lexicographic and psycholinguistic representation of the image of woman in different cultures] // Vestnik NGU. Ser.: Lingvistika i mezhkul'turnaya kommunikaciya. 2012. T. 10, vyp. 2. P. 45-50.

3. Vasil'eva S.P., Vasil'ev A.D., T.V. Mamaeva E.V. Ust'yanceva Bazovye cennosti regional'nogo yazykovogo soznaniya russkih Prienisejskoj Sibiri: monografiya [Basic values of regional linguistic consciousness of Russians in Yenisei Siberia: monograph]. Krasnoyarsk: KGPU im. V.P. Astaf'eva, 2017. 180 p.

4. Timchenko A.G. Lexical explication of the semiotic opposition "man/woman" in the dialects of the Central districts of the Krasnoyarsk territory [Lexical explication of the semiotic opposition "man / woman" in the dialects of the Central districts of the Krasnoyarsk territory]. Word and text in the cultural consciousness of the epoch: a Collection of scientific papers. Vologda state pedagogical University. Vologda, 2012. P. 250-256. 
5. Tarasov E.F. Problema analiza soderzhaniya obshchechelovecheskih cennostej [The problem of analyzing the content of universal values] // Voprosy psiholingvistiki. 2012. № 1 (15). P. 8-17.

6. Ust'yanceva E.V. Oppoziciya muzhchina - zhenshchina v yazykovom soznanii sibiryakov [Manwoman opposition in the linguistic consciousness of Siberians] // Bazovye cennosti etnosa v rechi i tekste: materialy mezhdunarodnoj nauchno-prakticheskoj konferencii. Krasnoyarsk: KGPU im. V.P. Astaf'eva, 2017. P. 261-269.

7. Ufimceva N.V. Russkie: opyt eshche odnogo samopoznaniya [Russian: the experience is one of self-discovery]. Etnokul'turnaya specifika yazykovogo soznaniya. M.: In-t yazykoznaniya RAN, 1996. P. 144-162.

\section{About the author}

Mamaeva Tatiana Vladimirovna - PhD in Philology, Associate Professor of the Department of General Linguistics, Krasnoyarsk State Pedagogical University named after V.P. Astafiev; e-mail: mamaevatv@yandex.ru 